Original Article

\title{
Decolorization of the benzidine-based azo dye Congo red by the new strain Shewanella xiamenensis G5-03
}

\author{
Descoloração do corante azo derivado da benzidina vermelho Congo por uma nova \\ linhagem de Shewanella xiamenensis G5-03
}

\author{
E. R. Silva ${ }^{a}$ (iD, E. L. Dall’Ogliob (D), L. G. Vasconcelos ${ }^{\mathrm{b}}$ (D) and E. B. Moraisa, ${ }^{\mathrm{a} *}$ (iD) \\ aUniversidade Federal de Mato Grosso - UFMT, Programa de Pós-graduação em Recursos Hídricos, Cuiabá, MT, Brasil \\ bUniversidade Federal de Mato Grosso - UFMT, Departamento de Química, Cuiabá, MT, Brasil \\ cUniversidade Federal de Mato Grosso - UFMT, Departamento de Engenharia Sanitária e Ambiental, Cuiabá, MT, Brasil
}

\begin{abstract}
Shewanella xiamenensis G5-03 was observed to decolorize the azo dye Congo red in synthetic wastewater. The influence of some factors on the dye decolorization efficiency was evaluated. The optimal decolorization conditions were temperature $30-35^{\circ} \mathrm{C}, \mathrm{pH} 10.0$, incubation time $10 \mathrm{~h}$, and static condition. The kinetic of Congo red decolorization fitted to the Michaelis-Menten model $\left(V_{\max }=111.11 \mathrm{mg} \mathrm{L}^{-1} \mathrm{~h}^{-1}\right.$ and $\left.K_{\mathrm{m}}=448.3 \mathrm{mg} \mathrm{L}^{-1}\right)$. The bacterium was also able to degrade benzidine, a product of azo bond breakage of the Congo red, which contributed to reduce the phytotoxicity. The ability of S. xiamenensis G5-03 for simultaneous decolorization and degradation of Congo red shows its potential application for the biological treatment of wastewaters containing azo dyes.
\end{abstract}

Keywords: kinetic study, bacterium, bioremediation, phytotoxicity.

\begin{abstract}
Resumo
Shewanella xiamenensis G5-03 foi capaz de descolorir o corante azo vermelho Congo em água residuária sintética. A influência de alguns fatores na eficiência da descoloração do corante foi avaliada. As condições ótimas de descoloração foram temperatura de $30-35^{\circ} \mathrm{C}, \mathrm{pH} 10,0$ e condições estáticas. A cinética de descoloração do vermelho Congo se ajustou ao modelo de Michaelis-Menten $\left(V_{\max }=111,11 \mathrm{mg} \mathrm{L}^{-1} \mathrm{~h}^{-1}\right.$ and $\left.K_{\mathrm{m}}=448,3 \mathrm{mg} \mathrm{L}^{-1}\right)$. A bactéria também foi capaz de degradar a benzidina, um produto da quebra da ligação azo do vermelho Congo, o que contribuiu para a redução da fitotoxicidade. A habilidade da S. xiamenensis G5-03 em simultaneamente descolorir e degradar o vermelho Congo demostra seu potencial de aplicação no tratamento de águas residuárias contendo corantes azo.
\end{abstract}

Palavras-chave: estudo cinético, bactéria, biorremediação, fitotoxicidade.

\section{Introduction}

The textile industry produces large volumes of effluents containing residues of dyes, metals, COD, BOD, total solids, and variable $\mathrm{pH}$ (Holkar et al., 2014). Because of that, they are the cause of serious environmental concerns. The discharge of textile-dye-containing effluent in aqueous ecosystems affects the aesthetic merits and transparency of water, diminishes the photosynthetic activity by reduction of sun penetration, and reduces oxygen transference into the water, which causes acute toxic effects in fish and other animals (Vikrant et al., 2018). Besides, many textile dyes and some of their metabolites are toxic, mutagenic, and carcinogenic (Saratale et al., 2011). Thus, they must be removed from the effluent before its disposal.

Several physicochemical effluent treatment processes, including coagulation, electrocoagulation, adsorption, ozonation, and photon-Fenton oxidation, have been reported for the removal of dyes (Castro et al., 2017).
Nevertheless, these methods possess inherent limitations such as high cost, the formation of sludge containing the dyes or their metabolites, and intensive requirements of energy (Cossolin et al., 2019). On the order hand, biotechnologies approaches using microorganisms for the remediation of effluents have been of considerable interest since they are cost-effective, environmentally friendly, and produce less sludge (Vikrant et al., 2018).

Microorganisms are the primary degraders of nature and have been applied to remediate different pollutants. Studies have reported different groups of decolorizing microorganisms, including bacteria, filamentous fungi, yeast, and algae (Chia et al., 2014; Holkar et al., 2014; Song et al., 2017). White-rot fungi are the most common microorganisms for this approach, because of their ability to produce some extracellular lignin enzymes, which are responsible for decolorizing dyes. However, a

*e-mail: beraldo_morais@yahoo.com.br

Received: April 29, 2020 - Accepted: August 31, 2020

This is an Open Access article distributed under the terms of the Creative Commons Attribution License, which permits unrestricted use, distribution, and reproduction in any medium, provided the original work is properly cited. 
long growth cycle limits the performance of the fungal decolorization system (Stolz, 2001). Bacteria can degrade and even mineralize many textile dyes under certain specific optimum cultural conditions. The features like omnipotence, faster growth, facultative nature, and high adaptability are the desirable qualities of the bacterial community for the textile dye bioremediation (Gomare et al., 2009).

In the past decade many bacterial strains belonging to different genera such as Klebsiella (Franciscon et al., 2009), Brevibacillus (Gomare et al., 2009), Comamonas (Jadhav et al., 2011), Pseudomonas (Hussain et al., 2013), Shewanella (Babu et al., 2013), Enterobacter (Holkar et al., 2014), and Acinetobacter (Anwar et al., 2014) have been reported to degrade azo dyes, the most important and most abundant class of synthetic dyes used in commercial applications (Saratale et al., 2011). Azo dyes are aromatic compounds with one or more azo bond ( $-\mathrm{N}=\mathrm{N}-)$. The bacterial degradation of azo dyes often is initiated by reductive cleavage of the azo bond, which results in the formation of colorless aromatic amines (Stolz, 2001). Azoreductase is the key enzyme responsible for this process, which occurs mainly in anaerobic conditions (Saratale et al., 2011).

In this study, Congo red, an azo dye also called Direct Red 28, was used as a model compound in a biological decolorization process using the bacteria Shewanella xiamenensis G5-03. Congo red is a recalcitrant compound and known to metabolize to benzidine, a human carcinogen. Nevertheless, it has been used in textile, paper, rubber, and plastics industries (El Messaoudi et al., 2016).

The genus Shewanella is widely distributed in nature and has been studied in applied and environmental microbiology (Venkateswaran et al., 1999). Bacteria of this genus are known for their respiratory diversity, which allows them to couple the degradation of organic compounds to the reduction of the various terminal electron acceptors (Fredrickson et al., 2008). This characteristic of Shewanella strains has attracted many interests for their application in the bioremediation of hazardous compounds, including azo dyes (Babu et al., 2013).

The purpose of this study was to investigate the potential of Shewanella xiamenensis G5-03 for decolorizing azo dye Congo red in synthetic wastewater. The influence of various environmental conditions on the dye decolorization process, such as $\mathrm{pH}$, temperature, dye concentration, static, and agitated incubation, was studied to achieve maximum dye degradation. Besides, the decolorization kinetic, benzidine from dye degradation, and their toxicity were also assessed.

\section{Material and Methods}

\subsection{Dye and chemicals}

Congo red (CR) was purchased from VETEC - SigmaAldrich, Brazil. A sterile stock solution of the dye $\left(1.0 \mathrm{~g} \mathrm{~L}^{-1}\right)$ was prepared using distilled water, and the sterilization was made by filtration through a $0.22 \mu \mathrm{m}$ membrane filter. All other chemicals used were of analytical grade.

\subsection{Culture media and synthetic wastewater}

Tryptic soy broth (TSB) used in bacterial inoculum production was purchased from Himedia Labs. Agar was added in TSB $(1.5 \% \mathrm{w} / \mathrm{v})$ to prepare a solid media used in stock cultures of the bacterial strain.

CR sterile stock solution was diluted in rich mineral medium, consisted of ( $\left.\mathrm{g} \mathrm{L}^{-1}\right): \mathrm{K}_{2} \mathrm{HPO}_{4} 1.6, \mathrm{KH}_{2} \mathrm{PO}_{4} 0.2$, $\left(\mathrm{NH}_{4}\right)_{2} \mathrm{SO}_{4} 1.0, \mathrm{MgSO}_{4} .7 \mathrm{H}_{2} \mathrm{O} 0.2, \mathrm{FeSO}_{4} .7 \mathrm{H}_{2} \mathrm{O} 0.01, \mathrm{NaCl}$ $0.1, \mathrm{CaCl}_{2} \cdot \mathrm{H}_{2} \mathrm{O} 0.02$, glucose 3.0 , and yeast extract 1.0 (Franciscon et al., 2009), at required concentration to create the synthetic dye loaded wastewater.

\subsection{Decolorizing bacterium and identification}

Details of the isolation and identification of decolorizing bacterium were described in our previous study (Cossolin et al., 2019). The identification was based on the sequencing of the $16 \mathrm{~S}$ ribosomal DNA (rDNA) gene, which was compared with the known sequences available in the GenBank using the BLASTn (https://blast.ncbi.nlm. nih.gov/Blast.cgi). Phylogenetic analysis was conducted by carrying out the multiple alignments using Clustal W (Thompson et al., 1994) and processing the data using the neighbor-joining method (Saitou and Nei, 1987). The 165 rDNA gene sequence of the Shewanella xiamenensis G503 has been deposited in GenBank under the accession number MN005116.

\subsection{Inoculum preparation and decolorization experiments}

A loopful of bacterial strain grown on the TSA plate ( $24 \mathrm{~h}, 35^{\circ} \mathrm{C}$ ) was inoculated in Erlenmeyer flask containing $100 \mathrm{~mL}$ TSB. The flask was incubated at $35^{\circ} \mathrm{C}$ in a rotary shaker (150 rpm) until the optical density $\left(\mathrm{OD}_{600}\right)$ of 1.0 was reached. This biomass was used as inoculum (5\% $\mathrm{v} / \mathrm{v}$ ) for all decolorization experiments. Decolorization experiments were carried out in Erlenmeyer flask containing $100 \mathrm{~mL}$ of synthetic dye loaded wastewater. Effects of temperature $\left(25,30,35,40^{\circ} \mathrm{C}\right)$, initial $\mathrm{pH}(5,7$, 10 , adjusted by the addition of $0.1 \mathrm{M} \mathrm{HCl}$ or $0.1 \mathrm{M} \mathrm{NaOH}$ solutions), dye concentration (50-750 $\mathrm{mg} \mathrm{L}^{-1}$ ), and static and agitated incubation were evaluated. Dye concentration was monitored spectrophotometrically at $\lambda_{\text {max }}$ of $497 \mathrm{~nm}$ (UV-Vis spectrophotometer Hach). The cells were removed by centrifugation (3600 rpm, $15 \mathrm{~min}$ ) before dye concentration determination. Uninoculated Erlenmeyer flasks were included to estimate the abiotic decolorization. The decolorization percentage was calculated according to Equation 1:

$$
\operatorname{Decolorization}(\%)=\frac{C_{i}-C_{f}}{C_{i}} \times 100
$$

where $C_{i}$ is the initial concentration of dye $\left(\mathrm{mg} \mathrm{L}^{-1}\right)$, and $C_{\mathrm{f}}$ is the concentration of dye $\left(\mathrm{mg} \mathrm{L}^{-1}\right)$ at reaction time $\mathrm{t}$ (hour).

\subsection{Measurement of biomass}

The bacterium biomass was determined by measuring the $\mathrm{OD}_{600}$ during the decolorization (Holkar et al., 2014): $\mathrm{OD}_{600}=\mathrm{OD}_{\text {sample }}-\mathrm{OD}_{\text {supernatant }}$. 


\subsection{Benzidine quantification}

Benzidine released from the reduction of $C R$ was quantified colorimetrically according to the method described by Oren et al. (1991). In $0.2 \mathrm{~mL}$ of decolorized synthetic wastewater, $0.8 \mathrm{~mL}$ of ultrapure water, $0.05 \mathrm{~mL}$ of $1 \mathrm{M} \mathrm{HCl}, 3 \mathrm{~mL}$ of ethanol, $0.5 \mathrm{~mL}$ of $5 \%$ p-dimethylaminobenzaldehyde in ethanol, and $0.5 \mathrm{~mL}$ of $15.7 \%$ citric acid in $6 \% \mathrm{NaOH}$ were added. After $10 \mathrm{~min}$, $2.5 \mathrm{~mL}$ of ultrapure water was added to the tubes, and benzidine was measured spectrophotometrically at $\lambda_{\max }$ of $440 \mathrm{~nm}$ (UV-Vis spectrophotometer Hach).

\subsection{Phytotoxicity studies}

Phytotoxicity tests using Ocimum basilicum and Eruca sativa seeds were performed in order to assess the toxicity of the original dye and its metabolites obtained after decolorization. For this, synthetic wastewater containing $50 \mathrm{mg} \mathrm{L}^{-1}$ of CR was submitted to decolorization by S. xiamenensis G5-03 for $120 \mathrm{~h}$. Then, ten seeds of each plant were grown in Petri plates with a supply of $5 \mathrm{~mL}$ of synthetic wastewater obtained at different time intervals during decolorization $(0,10$, and $120 \mathrm{~h})$ and incubated at $23 \pm 1{ }^{\circ} \mathrm{C}$ in the dark. Distilled water was used as control. After 7 days, germination (\%) and radicle lengths (cm) were recorded. The germination index (GI) was calculated according to Equation 2 (Gomare et al., 2009):

$$
G I(\%)=\frac{L s \times \% G s}{L c \times \% G c} \times 100
$$

where $L s$ and $L c$ are the length of radicles $(\mathrm{mm})$ in seeds treated with synthetic wastewater sample and distilled water (control), respectively. Gs and Gc are the numbers of seeds that germinated in synthetic wastewater sample and distilled water (control), respectively.

\subsection{Statistical analysis}

The results presented in this study are the mean of triplicate \pm standard deviations (SD). For the comparison of two levels of a single factor, the data were analyzed by the Student $t$ test. For the comparison of three or more than three levels of a single factor, data were analyzed by One-Way Analysis of Variance (ANOVA) by using Tukey multiple comparisons test. The $p$-values of less than 0.05 were considered to be statistically significant.

\section{Results and Discussion}

\subsection{Decolorizing bacterium}

The multiple alignments revealed that the 16S rDNA gene sequence of G5-03 showed $99.51 \%$ similarity to that of Shewanella xiamenensis. The phylogenetic relationship of the strain with other Shewanella species found in the GenBank is shown in Figure 1.

\subsection{Effect of $\mathrm{pH}$ and temperature on $\mathrm{CR}$ decolorization}

The $\mathrm{pH}$ and temperature play a crucial role in the optimal physiological performance of microorganisms during the decolorization process. Therefore, these factors were studied in detail during the CR decolorization. S. xiamenensis G5-03 showed the highest decolorization rates at $\mathrm{pH} 10.0(90.2 \%)$ and $\mathrm{pH} 7.0(71.7 \%)$ after $10 \mathrm{~h}$

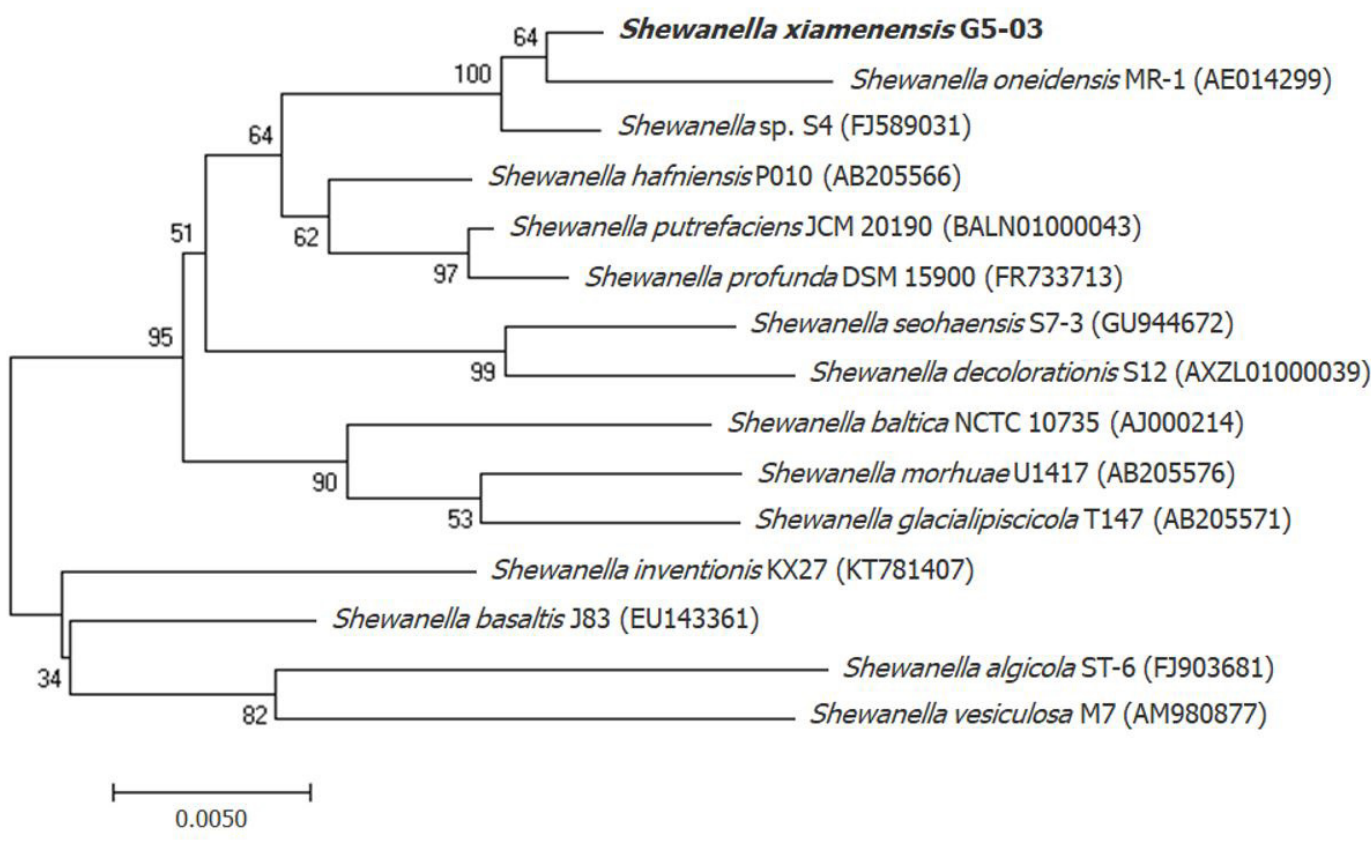

Figure 1. Neighbor-joining phylogenetic tree based on $16 \mathrm{~S}$ rDNA gene sequences showing the relationships of strain G5-03 with other Shewanella species found in the GenBank. Numbers at nod shows the percentage of 1000 bootstrap replicates. The bar indicates 0.005 substitutions per nucleotide position. 
of incubation, while at $\mathrm{pH} 5.0$, the decolorization rate reached $24.1 \%$ (Figure 2a). Statistical analysis conducted using One-Way ANOVA showed a significant difference $(p<0.00001)$ in the decolorization when carried out at different $\mathrm{pH}$ values. Further, Tukey multiple comparisons test showed that decolorization at $\mathrm{pH} 5$ was significantly lower when compared to those at $\mathrm{pH} 7(p=0.0011)$ and $\mathrm{pH} 10(p=0.0001)$. There was no significant difference in the decolorization between $\mathrm{pH} 7$ and 10. Considering that many dyes bind to the textile fibers by addition or substitution mechanisms under alkaline conditions, and hence the $\mathrm{pH}$ of effluent is usually higher than eight (Aksu and Dönmez, 2003), pH 10 was adopted to investigate bacterial decolorization in the subsequent experiments.

When the decolorization of CR by S. xiamenensis G5-03 was studied at different temperatures, it was found that the highest decolorization rates were obtained at $30{ }^{\circ} \mathrm{C}$ (97.5\%) and $35^{\circ} \mathrm{C}(90.2 \%)$ (Figure $\left.2 \mathrm{~b}\right)$. A further increase in temperature to $40{ }^{\circ} \mathrm{C}$ resulted in a marginal reduction in the decolorization activity (34.8\%), probably because of the slower growth rate and deactivation of enzymes responsible for degradation at such high temperatures. OneWay ANOVA showed a significant difference $(p<0.00001)$ in the decolorization at different temperatures. The Tukey's multiple comparisons test showed there was no significant difference between decolorization rates obtained at 30 and $35^{\circ} \mathrm{C}$. However, they were statistically higher than those decolorization rates found at 25 and $40{ }^{\circ} \mathrm{C}$.
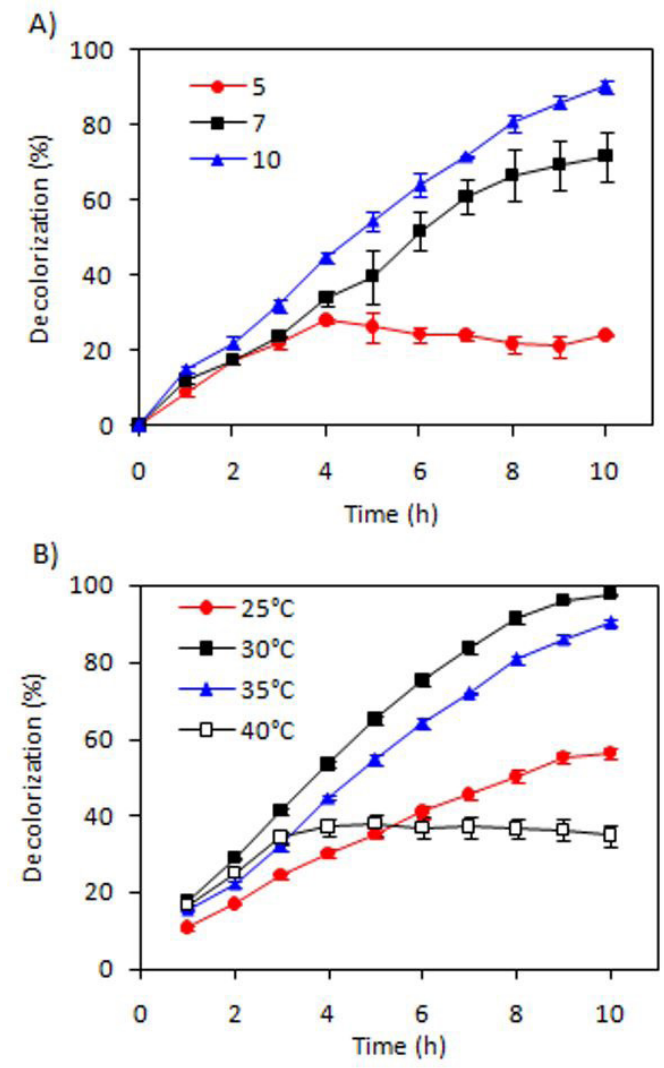

Figure 2. Effect of $\mathrm{pH}(\mathrm{A})$ and temperature (B) on the $\mathrm{CR}$ decolorization by S. xiamenensis G5-03.

\subsection{Effect of static/agitated incubation on $C R$ decolorization}

It was found that the growth of G5-03 strain was higher under agitated incubation (aerobic condition) as compared to static incubation (microaerophilic condition) (Figure 3). On the other hand, the agitation had a negative impact on the CR decolorization (14.1\% after $10 \mathrm{~h}$ ), while $90.2 \%$ of CR was decolorized in static condition. Statistical analysis conducted using the Student $t$ test showed a significant difference $(p<0.00001)$ between static and agitated incubation, indicating the inhibitory effect of oxygen on decolorization. The azo dye decolorization initiates with the reduction of azo bonds by azoreductases in a process that uses NADH as the electron donor. In aerobic conditions, the oxygen uses the electrons donated from NADH to form ATP depriving the azoreductase of obtaining electrons to decolorize the azo dyes (Chang et al., 2001). Some studies have reported that dye decolorization under static/microaerophilic conditions is more efficient if compared to agitation/ aerobic conditions. Comamonas sp. UVS exhibited dyedecolorizing activity only when incubated under static conditions (Jadhav et al., 2011). Micrococcus glutamicus NCIM-2168 was able to completely decolorized the dye Reactive Green 19A after $42 \mathrm{~h}$ under static condition, whereas only $30 \%$ of the dye was decolorized under aerobic condition (Saratale et al., 2009). Only 20\% of Remazol Red dye was decolorized by Lysinibacillus sp. RGS after $6 \mathrm{~h}$ in agitated condition while the dye color was completely removed in static condition (Saratale et al., 2013).

\subsection{Decolorization kinetic model}

Michaelis-Menten model has been widely used to describe the dye decolorization kinetics by enzymes or living cells (Holkar et al., 2014). The two model parameters $\left(V_{\max }\right.$ and $\left.K_{\mathrm{m}}\right)$ are calculated according to Equation 3:

$$
V_{0}=\frac{V_{\max } S}{K_{m}+S}
$$

where $S$ is the substrate (dye) concentration $\left(\mathrm{mg} \mathrm{L}^{-1}\right), V_{\max }$ is the maximum specific decolorization rate $\left(\mathrm{mg} \mathrm{L}^{-1} \mathrm{~h}^{-1}\right)$, and

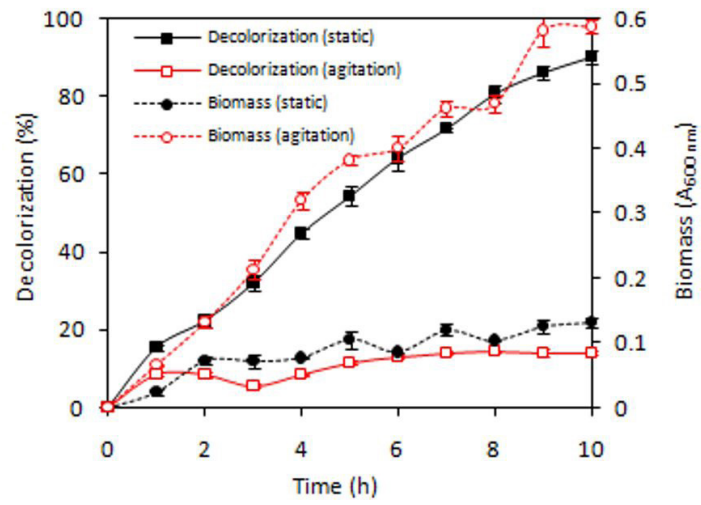

Figure 3. Effect of agitated and static incubation on CR decolorization by S. xiamenensis G5-03. 
$K_{\mathrm{m}}$ is the half-saturation constant $\left(\mathrm{mg} \mathrm{L}^{-1}\right)$. The MichaelisMenten equation was transformed into the double reciprocal form: $1 / V_{0}=K_{\mathrm{m}} /\left(V_{\max } S\right)+1 / V_{\max }$, to determine $V_{\max }$ and $K_{\mathrm{m}}$. A plot of $1 / V_{0}$ versus $1 / S$ yields a straight line with a slope of $K_{\mathrm{m}} / V_{\max }$ and an intercept of $1 / V_{\max }$.

When the initial CR concentration increased from 50 to $750 \mathrm{mg} \mathrm{L}^{-1}$, the CR degradation rate significantly increased from 19.9 to $55.8 \mathrm{mg} \mathrm{L}^{-1} \mathrm{~h}^{-1}$ (Figure $4 \mathrm{a}$ ). The corresponding linear regression equation from the plot of $1 / V_{0}$ versus $1 / \mathrm{S}$ is $\mathrm{y}=4.035 \mathrm{x}+0.009\left(R^{2}=0.949\right)$ (Figure $\left.4 \mathrm{~b}\right)$. Thereby, the obtained constants were $V_{\max }=111.11 \mathrm{mg} \mathrm{L}^{-1} \mathrm{~h}^{-1}$ and $K_{\mathrm{m}}=448.3 \mathrm{mg} \mathrm{L}^{-1}$.

\subsection{Benzidine quantification}

Degradation of CR usually proceeds by reduction of its azo bonds, resulting in the release of benzidine and other aromatic amines. Figure 5 shows the benzidine concentration in synthetic wastewater during CR decolorization by S. xiamenensis G5-03. The concentration of benzidine decreased from $17.2 \mathrm{mg} \mathrm{L}^{-1}$ (at $10 \mathrm{~h}$ ) to $5.3 \mathrm{mg}$ $\mathrm{L}^{-1}$ (at $120 \mathrm{~h}$ ), indicating that the bacterium was not only able to break the azo bonds but also degrade the benzidine.

\subsection{Phytotoxicity studies}

Two agriculturally valuable plant seeds, i.e., Ocimum basilicum and Eruca sativa, were used for the phytotoxicity
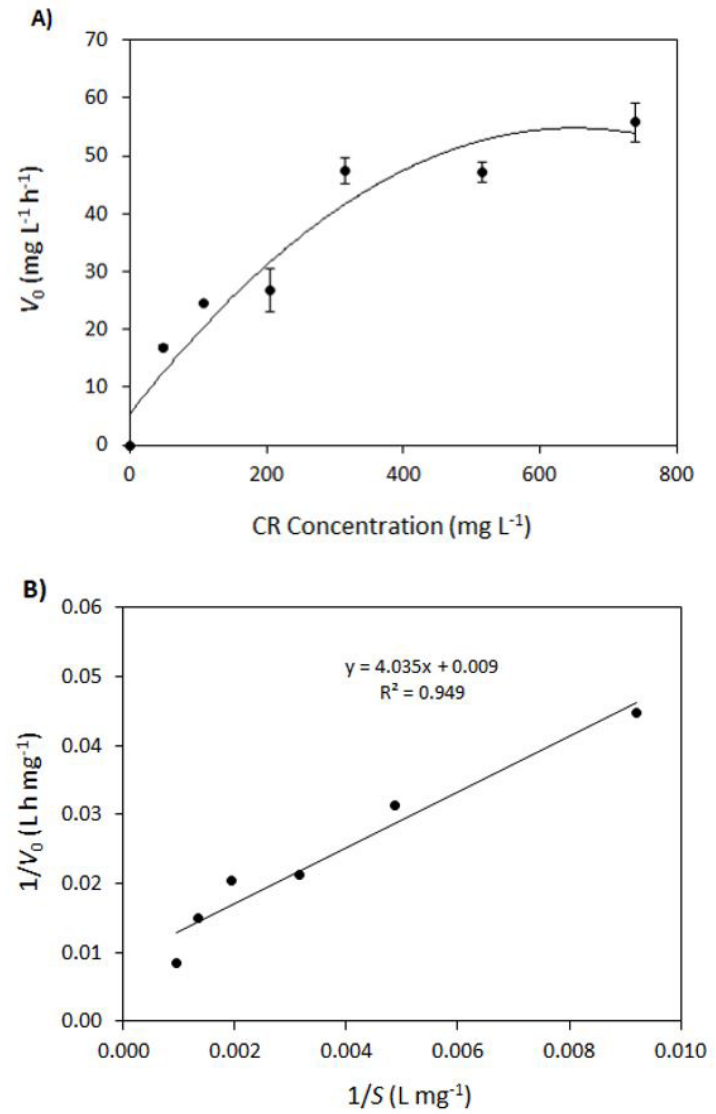

Figure 4. (A) Effect of $C R$ concentration on specific decolorization rate; (B) The double reciprocal plot of initial decolorization rate against $\mathrm{CR}$ concentration. assessment of the $\mathrm{CR}$ and its decolorization products. As shown in Figure 6, the germination indexes (GI) of $O$. basilicum and $E$. sativa that were grown in untreated synthetic wastewater were 74.0 and $88.3 \%$, respectively, and after $10 \mathrm{~h}$ of decolorization, decreased to 38.1 and $41.9 \%$. These results indicated that the decolorization products, including benzidine formed during the cleavage of azo bonds, are more toxic than the CR. With an extended decolorization time ( $120 \mathrm{~h}$ ), the GI increased to 58.0 and $72.6 \%$ for 0 . basilicum and $E$. sativa, respectively, presumably due to the degradation of benzidine and other toxic compounds. As indicated by Nouren \& Bhatti (2015), GI values lower than $50 \%$ represents high phytotoxicity, values falling between $50-80 \%$ represent moderate phytotoxicity, and values above $80 \%$ represent nontoxic effects. Therefore, phytotoxicity tests indicated that CR decolorization by $S$. xiamenensis G5-03 led to partial detoxification of the dye.

\section{Conclusion}

The strain S. xiamenensis G5-03 can decolorize the azo dye Congo red and degrade the benzidine, a product of

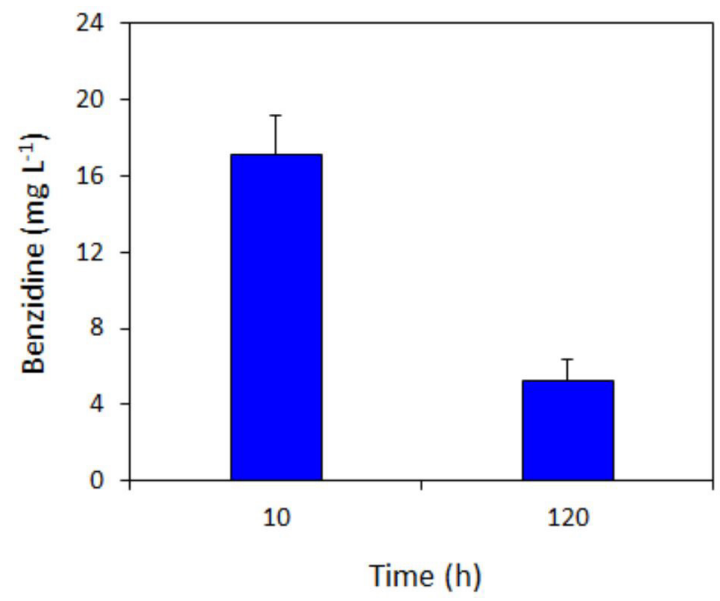

Figure 5. Changes in the concentration of benzidine during decolorization of CR by S. xiamenensis G5-03.

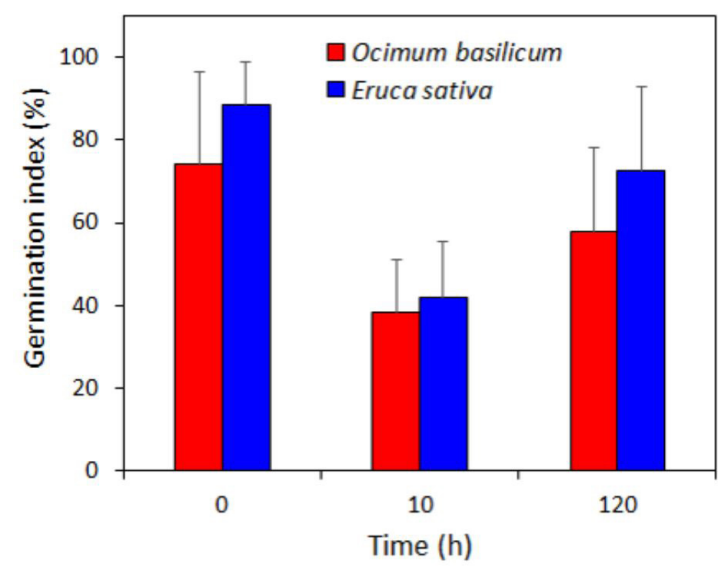

Figure 6. Evolution of phytotoxicity (germination index) during the CR decolorization by S. xiamenensis G5-03. 
the cleavage of the dye. The optimal conditions for the decolorizing activity were static incubation at $\mathrm{pH} 10.0$, and $30-35{ }^{\circ} \mathrm{C}$. Considering that many textile wastewaters are usually alkaline with $\mathrm{pH}$ higher than eight, this strain could be useful for the biological treatment of this kind of wastewater. The decolorization kinetic could be described with the Michaelis-Menten model, and the $V_{\max }$ and $K_{\mathrm{m}}$ were found to be $111.11 \mathrm{mg} \mathrm{L}^{-1} \mathrm{~h}^{-1}$ and $448.3 \mathrm{mg} \mathrm{L}^{-1}$, respectively. According to these findings, S. xiamenensis G5-03 might be valuable for the bioremediation of Congo red dye.

\section{Acknowledgements}

This study was financed in part by the Coordenação de Aperfeiçoamento de Pessoal de Nível Superior - Brasil (CAPES) - Finance Code 001 and by the Conselho Nacional de Desenvolvimento Científico e Tecnológico - Brasil (CNPq) - under Grant 486168/2013-1.

\section{References}

AKSU, Z. and DÖNMEZ, G., 2003. A comparative study on the biosorption characteristics of some yeasts for Remazol Blue reactive dye. Chemosphere, vol. 50, no. 8, pp. 1075-1083. http:// dx.doi.org/10.1016/S0045-6535(02)00623-9. PMid:12531715.

ANWAR, F., HUSSAIN, S., RAMZAN, S., HAFEEZ, F., ARSHAD, M., IMRAN, M., MAQBOOL, Z. and ABBAS, N., 2014. Characterization of reactive red-120 decolorizing bacterial strain Acinetobacter junii FA10 capable of simultaneous removal of azo dyes and hexavalent chromium. Water, Air, and Soil Pollution, vol. 225 , no. 8, pp. 1-16. http://dx.doi.org/10.1007/s11270-014-2017-7.

BABU, S.S., MOHANDASS, C., RAJ, A.S.V., RAJASABAPATHY, R. and DHALE, M.A., 2013. Multiple approaches towards decolorization and reuse of a textile dye (VB-B) by a marine bacterium Shewanella decolorationis. Water, Air, and Soil Pollution, vol. 224 no. 4, pp. 1-12. http://dx.doi.org/10.1007/s11270-013-1500-x.

CASTRO, K.C., COSSOLIN, A.S., REIS, H.C.O. and MORAIS, E.B., 2017. Biosorption of anionic textile dyes from aqueous solution by yeast slurry from brewery. Brazilian Archives of Biology and Technology, vol. 60, no. 60, pp. 1-13. http://dx.doi. org/10.1590/1678-4324-2017160101.

CHANG, J.-S., CHOU, C., LIN, Y.-C., LIN, P.-J., HO, J.-Y. and LEE HU, T.2001. Kinetic characteristics of bacterial azo-dye decolorization by Pseudomonas luteola. Water Research, vol.35, no. 12, pp. 2841-2850. http://dx.doi.org/10.1016/S0043-1354(00)00581-9. PMid:11471684.

CHIA, M.A., ODOH, O.A. and LADAN, Z., 2014. The indigo blue dye decolorization potential of immobilized Scenedesmus quadricauda. Water, Air, and Soil Pollution, vol. 225, no. 4, pp. 1-9. http://dx.doi.org/10.1007/s11270-014-1920-2.

COSSOLIN, A.S., REIS, H.C.O., CASTRO, K.C., SANTOS, B.A.P., MARQUES, M.Z., PARIZOTTO, C.A., DALLOGLIO, E.L., VASCONCELOS, L.G. and MORAIS, E.B., 2019. Decolorization of textile azo dye Reactive Red 239 by the novel strain Shewanella xiamenensis G5-03 isolated from contaminated soil. Revista Ambiente \& Água, vol. 14, no. 6, pp. 1-11. http://dx.doi.org/10.4136/ambi-agua.2446.

EL MESSAOUDI, N., EL KHOMRI, M., DBIK, A., BENTAHAR, S., LACHERAI, A. and BAKIZ, B., 2016. Biosorption of Congo red in a fixed-bed column from aqueous solution using jujube shell: experimental and mathematical modeling. Journal of Environmental Chemical Engineering, vol. 4, no. 4, pp. 38483855. http://dx.doi.org/10.1016/j.jece.2016.08.027.
FRANCISCON, E., ZILLE, A., FANTINATTI-GARBOGGINI, F., SILVA, I.S., CAVACO-PAULO, A. and DURRANT, L.R., 2009. Microaerophilicaerobic sequential decolourization/biodegradation of textile azo dyes by a facultative Klebsiella sp. strain VN-31. Process Biochemistry, vol. 44, no. 4, pp. 446-452. http://dx.doi. org/10.1016/j.procbio.2008.12.009.

FREDRICKSON, J.K., ROMINE, M.F., BELIAEV, A.S., AUCHTUNG, J.M., DRISCOLL, M.E., GARDNER, T.S., NEALSON, K.H., OSTERMAN, A.L., PINCHUK, G., REED, J.L., RODIONOV, D.A., RODRIGUES, J.L.M., SAFFARINI, D.A., SERRES, M.H., SPORMANN, A.M., ZHULIN, I.B. and TIEDJE, J.M., 2008. Towards environmental systems biology of Shewanella. Nature Reviews. Microbiology, vol. 6, no. 8, pp. 592-603. http://dx.doi.org/10.1038/nrmicro1947. PMid:18604222.

GOMARE, S.S., TAMBOLI, D.P., KAGALKAR, A.N. and GOVINDWAR, S.P., 2009. Eco-friendly biodegradation of a reactive textile dye Golden Yellow HER by Brevibacillus laterosporus MTCC 2298. International Biodeterioration E' Biodegradation, vol. 63, no. 5, pp. 582-586. http://dx.doi.org/10.1016/j.ibiod.2009.03.005.

HOLKAR, C.R., PANDIT, A.B. and PINJARI, D.V., 2014. Kinetics of biological decolorisation of anthraquinone based Reactive Blue 19 using an isolated strain of Enterobacter sp.F NCIM 5545. Bioresource Technology, vol. 173, pp. 342-351. http://dx.doi. org/10.1016/j.biortech.2014.09.108. PMid:25310871.

HUSSAIN, S., MAQBOOL, Z., ALI, S., YASMEEN, T., IMRAN, M., MAHMOOD, F. and ABBAS, F., 2013. Biodecolorization of Reactive Black- 5 by a metal and salt tolerant bacterial strain Pseudomonas sp. RA20 isolated from Paharang drain effluents in Pakistan. Ecotoxicology and Environmental Safety, vol. 98, pp. 331-338. http://dx.doi.org/10.1016/j.ecoenv.2013.09.018. PMid:24138897.

JADHAV, U.U., DAWKAR, V.V., KAGALKAR, A.N. and GOVINDWAR, S.P., 2011. Effect of metals on decolorization of Reactive Blue HERD by Comamonas sp. UVS. Water, Air, and Soil Pollution, vol. 216, no. 1-4, pp. 621-631. http://dx.doi.org/10.1007/s11270-010-0557-z.

NOUREN, S. and BHATTI, H.N., 2015. Mechanistic study of degradation of basic violet 3 by Citrus limon peroxidase and phytotoxicity assessment of its degradation products. Biochemical Engineering Journal, vol. 95, pp. 9-19. http://dx.doi. org/10.1016/j.bej.2014.11.021.

OREN, A., GUREVICH, P. and HENIS, Y., 1991. Reduction of nitrosubstituted aromatic compounds by the halophilic anaerobic eubacteria Haloanaerobium praevalens and Sporohalobacter marismortui. Applied and Environmental Microbiology, vol. 57, no. 11, pp. 3367-3370. http://dx.doi. org/10.1128/AEM.57.11.3367-3370.1991. PMid:1669931.

SAITOU, N. and NEI, M., 1987. The neighbor-joining method: a new method for reconstructing phylogenetic trees. Molecular Biology and Evolution, vol. 4, no. 4, pp. 406-425. http://dx.doi. org/10.1093/oxfordjournals.molbev.a040454. PMid:3447015.

SARATALE, R.G., GANDHI, S.S., PURANKAR, M.V., KURADE, M.B., GOVINDWAR, S.P., OH, S.E. and SARATALE, G.D., 2013. Decolorization and detoxification of sulfonated azo dye C.I. Remazol Red and textile effluent by isolated Lysinibacillus sp. RGS. Journal of Bioscience and Bioengineering, vol. 115, no. 6, pp. 658-667. http://dx.doi.org/10.1016/j.jbiosc.2012.12.009. PMid:23321576.

SARATALE, R.G., SARATALE, G.D., CHANG, J.S. and GOVINDWAR, S.P., 2009. Ecofriendly degradation of sulfonated diazo dye C.I. Reactive Green 19A using Micrococcus glutamicus NCIM-2168. Bioresource Technology, vol. 100, no. 17, pp. 3897-3905. http:// dx.doi.org/10.1016/j.biortech.2009.03.051. PMid:19375909.

SARATALE, R.G., SARATALE, G.D., CHANG, J.S. and GOVINDWAR, S.P., 2011. Bacterial decolorization and degradation of azo dyes: A review. Journal of the Taiwan Institute of Chemical Engineers, vol. 42, no. 1, pp. 138-157. http://dx.doi.org/10.1016/j. jtice.2010.06.006. 
SONG, L., SHAO, Y., NING, S. and TAN, L., 2017. Performance of a newly isolated salt-tolerant yeast strain Pichia occidentalis G1 for degrading and detoxifying azo dyes. Bioresource Technology, vol. 233, pp. 21-29. http://dx.doi.org/10.1016/j.biortech.2017.02.065. PMid:28258992.

STOLZ, A., 2001. Basic and applied aspects in the microbial degradation of azo dyes. Applied Microbiology and Biotechnology, vol. 56, no. 1-2, pp. 69-80. http://dx.doi.org/10.1007/ s002530100686. PMid:11499949.

THOMPSON, J.D., HIGGINS, D.G. and GIBSON, T.J., 1994. CLUSTAL W: improving the sensitivity of progressive multiple sequence alignment through sequence weighting, position-specific gap penalties and weight matrix choice. Nucleic Acids Research, vol. 22, no. 22, pp. 4673-4680. http://dx.doi.org/10.1093/nar/22.22.4673. PMid:7984417.
VENKATESWARAN, K., MOSER, D.P., DOLLHOPF, M.E., LIES, D.P., SAFFARINI, D.A., MACGREGOR, B.J., RINGELBERG, D.B., WHITE, D.C., NISHIJIMA, M., SANO, H., BURGHARDT, J., STACKEBRANDT, E. and NEALSON, K.H., 1999. Polyphasic taxonomy of the genus Shewanella and description of Shewanella oneidensis sp. nov. International Journal of Systematic Bacteriology, vol. 49, no. Pt 2, pp. 705-724. http://dx.doi.org/10.1099/00207713-49-2-705. PMid: 10319494.

VIKRANT, K., GIRI, B.S., RAZA, N., ROY, K., KIM, K.H., RAI, B.N. and SINGH, R.S., 2018. Recent advancements in bioremediation of dye: current status and challenges. Bioresource Technology, vol. 253, pp. 355-367. http://dx.doi.org/10.1016/j.biortech.2018.01.029. PMid:29352640. 